\title{
Strengthening Local Institutional Identity Through Traditional Village Management
}

\author{
I Gusti Ayu Purnamawati \\ purnamawatiayu07@gmail.com \\ Universitas Pendidikan Ganesha
}

\begin{abstract}
This study aims to determine the driving factors for the development of the Sepandan Pantai area in Amed Village; and the influence of the involvement of traditional village elites on strengthening the identity of local institutions. The development of research findings in the field is integrated with cultural research. The research location is in Amed Village, Abang District, Karangasem Regency. The research data consisted of primary and secondary data. Primary data collection techniques are obtained through a process of observation and direct interviews with respondents and resource persons based on interview guidelines. The data analysis technique used in this research is descriptive qualitative. Results: The embodiment of the traditional Balinese spatial concept at the Amed Beach border is expected to be able to accommodate the concepts and philosophies of Tri Hita Karana, the concepts of Tri Angga, Luan Teben, Catus Patha and Sanga Mandala, resulting in a hierarchy and spatial structure in accordance with the conceptual formulation in its implementation. The space distribution created is based on the basic output of the concept of traditional Balinese spatial patterns. Spatial orientation on the Amed coastline. Based on the cosmological arrangement of Balinese philosophy and the concept of traditional space, it gives the meaning of harmony between space and its contents, within the scope of the coastal area of Amed Traditional Village.
\end{abstract}

Keywords : amed, beach border area, traditional village.

\section{Introduction}

The "Island of the Gods" in Indonesia, namely Bali Island, is one of the islands that has become a destination for a region equivalent to the world's coast by bringing in tourists from various parts of the world and showing a significant increase in visits every year. The panoramic beauty of the coastal area of the island of Bali which is wrapped in the unique cultural treasures of its people has made Bali famous for its culture and has become an icon of the region's equivalent to the world's beaches. The hospitality of the people, with the socio-cultural environment of its people that is so unique and religious that is based on belief and religion combined harmoniously with local wisdom makes Bali very popular.

As a mainstay of the Balinese economy, most of its population lives with the tourism sector. One of the added values that can bring financial sales value is a coastal area. The natural beauty that becomes the most dominating tourist attraction is the beach area. Adequate coastal area support infrastructure readiness and human resources involved in the tourism industry services need to be prepared to anticipate the high interest in visiting Bali. The tourism industry is an income-supporting sector for local residents who are generally local residents who pursue routines in agriculture, medium industry and civil servants as well as private employees. Coordination with related ranks, such as the village government, traditional villages, the Association of Indonesian Hotels and Restaurants (PHRI), including the local traditional village manners, needs to be continuously developed so that the tourism industry managed can maintain a balance between humans and God, humans with others, and humans with the environment. 


\section{Literature Review}

Tourism development, like the development of other fields, has an impact on the environment. The effect can be positive or negative. For less developed areas, tourism development can improve the environment for both tourists and local residents through improved sanitation, sewage systems and For areas that are already developed, tourism development seems to be paid attention to its negative aspects such as pollution and congestion (traffic). The natural environment is the main attraction for tourists. Tourists tend to be attracted to areas with beautiful panoramas, pleasant climates and views that are different from the others. In order to meet the tastes of tourists, some development is needed. Roads must be built so that the area is easily accessible, lodging houses must also be built for tourists, as well as restaurants must be available. In the best conditions tourism development should leave everything natural while things are needed tourists are also available. But in many circumstances, tourism development conflicts with the environment. There is no doubt that tourism has a positive effect on environmental conservation. Tourism stimulates the rehabilitation of historical sites, buildings and monuments. Tourism provides an impetus for development. Old buildings become new tourist attractions. Furthermore, tourism encourages the preservation of natural resources. An impact that is no less important is that the community around the object becomes more aware of the potential that exists in the object and seeks to anticipate it, especially in terms of improving the quality of human resources.

The policies issued have always prioritized the coastal area sector. On the other hand, many places that have become conservation areas or areas that are sterile from development have turned into tourist huts or hotels. As happened in Karangasem Regency, there have been many uses of coastal border areas which should have been converted into conservation areas and protected areas that have changed their function to become tourist huts lined up luxury along the coast.

This neglect of cultural space is evident along road sections in an area commensurate with the coast which is the center of the Amed tourism industry which is dominated or closed by commercial and tourist buildings. This condition is accepted as a fact of life in the landscape of tourist areas and is an economic choice, taking into account all the social, cultural and moral consequences as a direct impact and influence of the policies imposed in this area. The relationship between customary villages and tourism industrial areas appears to be a dilemma, with the conflict over cultural space mentioned above. The dominance of commercial space in this tourist area can be classified into three major groups, namely (1) small commercial buildings in the form of outlets or storefronts for certain products, shops for daily needs of tourists known as minimarkets, service places, such as laundry, money changer and others; (2) recreational building groups and tourist entertainment, such as: spas, karaoke, cafes and restaurants; and (3) groups of large and spacious buildings for tourist accommodation, such as inns, budget hotels, star hotels to tour and travel agency company terminals (Dinas Pariwisata, 2014).

The problem that then develops is that the management of maritime areas has not been matched by a management system that is able to maintain the balance of the surrounding environment. The coastal border area is an area that is very vulnerable to violations and misuse of functions carried out by certain parties which result in changes that occur so it is necessary affirmation that the coastal border area is a protected area. Generally, many tourist huts are established in coastal border areas to add to the panorama and beauty (Djunarjah, 2011). This condition has an impact on the sustainability of the coastal environment and the life of traditional fishermen. The practice which was carried out in 2001 in the Bali coastal area showed that $20 \%$ of the 438 long beaches in Bali were damaged. The phenomenon of the large number of buildings along the coast and damage to the coastal environment as well as the interests of marginalized fishermen must immediately receive serious attention and treatment. To prevent further damage to the coast, it is necessary to have a coastal border area. The area known as the coastal border must be made into a conservation area. In the Decree of the Presidential Decree No. 32 of 1990, the protection of coastal borders as far as 100 meters is regulated. And also Regional Regulation No. 16 of 2009 concerning the Regional Spatial Plan 
(Perda RTRW) of Bali Province. The existing regulations should be obeyed, enforced and followed up with implementing regulations under them at both the central and regional levels (Adnyani, 2016: 139).

Based on Adnyani's study (2016), referring to the Bali Province Regional Spatial Planning Regional Regulation, there are actually many areas that should be protected by the government and the community. Based on Article 44 paragraph (1) of the Bali Provincial Regulation Number 16 of 2009 concerning the Spatial Plan for the Province of Bali for 20092029 , the coastal border area is one of the areas included in the protected area.

\section{Research Methods}

This research uses qualitative methods with a framework of interpretative cultural studies or cultural studies, theories that become the basis of research or analysis references, constructed eclectically in accordance with the concept of multidisciplinary research. The object of this research is social reality which includes the movement of individuals and institutions within it, with identities, values, culture, traditions, and local communities in an area commensurate with Amed beach. Social reality in this case is in line with the management of tourist lodges in the context of developing a coastal area.

Participatory approach as a tourism actor (tour guide) and literature search, the problem to be answered is regarding the two sides of interest in tourism development for Balinese people in the socio-economic dimension and cultural preservation and development, Pemayun \& Meirejeki (2016). Descriptive data generated in the study, either in the form of oral, written data, or documents from competent sources and informants (key and expert) will be collected using qualitative exploratory research methods and techniques.

Researchers as an instrument go directly to the field with involved or participatory observations to make observations, record, and take photo documentation, sound recordings and so on during significant processes. This exploratory research technique is carried out to obtain data in the form of detailed descriptive information about the meaning an object, action, interaction and events related to people's lives. In this case, the researcher explores the subject side, from the mindset, attitudes and praxis in cultural actions as well as economic actions of local communities in the dynamics of development in an area commensurate with the Amed coast.

The potential of the coastal area of the traditional village of Amed as a community-based tourism village has a very large potential to be developed as a community-based tourism village, because of the direct involvement of the local community, with its various customary regulations as outlined in the Awig-awig of the Adat Amed Village, so that it has various good impacts. For the local community and local government in Karangasem Regency.

The impact on development from an economic point of view, with the stipulation of Amed Village as a tourist village, the local community directly and indirectly get economic benefits as direct benefits of obtaining additional income from the sale of souvenirs to tourists visiting people's homes. While the benefits are indirectly obtained through the receipt of admission tickets paid by tourists who enter the treasury of the Traditional Village, which can later be used to finance the needs of the Traditional Village so that it can alleviate the amount of compensation that must be issued by the villagers. Other impacts are also obtained by the local government in the form of income from entrance tickets to tourism objects which are part of regional revenue for Karangasem Regency.

The environmental aspect is very important in tourism development, considering the trend of tourists visiting a tourist area is very sensitive to environmental problems in addition to the educational level of tourists today, they tend to be highly educated so that their curiosity is getting bigger. already has this as a potential, this can be seen from the arrangement of the rural environment in such a way that it looks very beautiful and neat, for example, it can be seen from the composition of residential areas, sacred areas, and moor which are maintained. And awareness from local residents to keep the environment clean. 
Planning and development of a coastal area in Amed Traditional Village as a Tourism Village has a very positive effect on the existing physical environment, this is reflected in that since the development of this village into a tourist village, the environment looks more organized, clean, beautiful, beautiful and sustainable.

Local communities in the area commensurate with the Amed coast became involved directly, in response to the need for interaction with tourists. In this way, the citizens reacted proactively. That is where the involvement of villagers began, for example in repairing houses, establishing souvenir stalls, and prohibiting scavengers and traders in an area similar to Amed beach.

The traditional village of Amed has a very good potential as a Tourism Village community-based, therefore the local government should provide more intensive counseling to the indigenous village community of Amed, related to the Community-based Sustainable Tourism Development Program, which is environmentally sound, and to increase the ability of local residents to conduct cross cultural communication with tourists.

It is hoped that this village development program will soon hold outreach to the villagers, and the Amed Traditional Village community is involved as much as possible in the planning, implementation, supervision and enjoyment of the results so that a sense of responsibility and ownership will arise. To further increase the involvement of the local community, it is necessary to consider the existence of a local guide formed by Amed Traditional Village, to guide tourists visiting Amed Tourism Object. Here it is hoped that the attention of the government, the private sector and the academic world to participate in educating and fostering local residents to be trained as professional local guides, because these local guides know more about the cultural potential in the area.

The Amed Traditional Village was made a Tourism Village. As for the potential that is owned are as follows: the unique customs and the high frequency of traditional religious ceremonies. b. The physical appearance of the Traditional Village is also very unique and beautiful, where the main village road is a narrow straight and statutory road, and at the north end of the road there is the majestic and beautiful Penataran Temple, while at the south end of the road there is a grave and a hero monument (historical tourism). House roofs made of bamboo, yard walls and angkul-angkul that still apply the old pattern, which line the linear road from north to south, show the togetherness and order of the Penglipuran community. The angkul-angkul are a kind of trade mark for the Amed Traditional Village.

The potential of the coastal area of Amed traditional village as a populist-based tourism village with various uniqueness, the Amed traditional village has a very large potential to be developed as a community-based tourism village, due to the direct involvement of the local community, with its various customary regulations as outlined in Awig-awig traditional village of Amed, so that it has various good impacts for the local community and local government in Karangasem Regency.

The carrying capacity of the Strategic Tourism Area with a panoramic view of the coast as a driving force for the existence of the Traditional Village of Amed as a tourism village based on the people such as village history, spatial structure, organizational system customs and other uniqueness.

\section{Analysis and Discussion}

\subsection{The Driving Factors for The Development of The Sepandan Pantai Area In Amed Village}

Tourism has been developed in Bali for more than half a century, and hence it has become an integral part of Balinese culture, Pitana (2010). The interaction between humanculture-environment for design purposes is to achieve the level of "conformity". The interaction of human culture and the environment can be observed through the arrangement which is the interaction unit of the three elements. The alignment of macro and micro elements gave birth to the concept of the Sanga Mandala spatial pattern which is more specifically based on the Tri Angga concept (three parts of the body composition), which is primarily oriented towards the rising sun as the sun's axis and towards the highest mountain based on the earth's axis, while 
the Nistanya direction oriented towards the setting sun on the axis of the sun and towards the sea on the axis of the earth. Thus, if the mountains are in the north and the sea is in the south, imaginary the Sanga Mandala pattern will be formed. The spatial pattern of settlements in Amed Traditional Village has a very close relationship with nature and the environment as a result of family expansion or developments carried out by the government including science, technology, health, tourism and others which can affect natural relations. and the environment that has been going on for generations. A certification was carried out based on this philosophy, to give an indication whether tourism sectors, especially the hotel sector in this province move toward sustainable direction (Dalem, 2014).

Descriptively, the consideration of the choice of Amed Beach Area as a research, among others, is due to the existence of various activity patterns such as ritual activities (melasti, throwing ash, mesampilan, melukat), recreational tourism and changes in land use patterns which are the impact of the tourism industry, with the cultural allusion of modernity as the result of development with all its impacts in the southeast will result in changes in structure, livelihoods and result in a process of adaptation to the environment, thus causing cultural acculturation of traditional Balinese Spatial Patterns which in turn affect changes in the embodiment of regional spatial planning (macro) or its settlements (micro).Partnership cooperation with related agencies has not been able to be developed in related to the development of cultural tourism (Yudana, et al, 2020).

Tourism village development, in the planning process must involve from the beginning local community, Sudiatmaka \& Adnyani (2020). Amed Beach which is an area that has a unique existence and a large variety of activities contained in it, the magnitude of development pressure, especially in the tourism sector, greatly impacts the development development in Amed Traditional Village. The existence that is built in the Amed Beach area includes: temples, residential areas, fish storage areas (warehouses), villas / bungalows. The pattern of activities at Amed Beach includes: surfing, bathing, ritual places, recreation and so on. The potential for mixed land use results in complexity resulting from community activities. The scope of the arrangement is the basis for the study research, namely: the physical boundaries of the holy place, the condition of the existing villa / bungalow, the pattern of community activities, and the community organization system.

The heterogeneous pattern of activity on the border of Amed Beach which is used as a place of ritual by the Amed community in particular and the Balinese people in general (melasti, throwing ash, melukat, mesampilan) is also used as a boat landing dock for fishermen and the location of tourism objects, both domestic and domestic tourists. foreign countries, so that it has an impact on mixed land use, for example in one location there are various kinds of activity patterns, namely the location of melasti, dumping ashes, messengers sometimes mixed into one, but the pattern of non-ritual activities adjusts to ritual activities. Patterns of activity, support or motivation for conditions and natural character both in terms of the physical area, the potential for beauty / attractiveness or other potential have an effect on the shifting of spatial functions in Amed Traditional Village. At Amed Beach there are two classifications of activity patterns, namely activities that are religious rituals and activities that are social / non-religious in nature.

Bengen (2000) in this study focuses on the development of coastal and coastal areas so that they can be environmentally sound and sustainable, must be done with a protected area approach, with the following objectives: (1) Protecting critical habitats. (2) Maintaining biodiversity (3) Conserving fish resources so that they do not become extinct. (4) Protecting the coastline. (5) Protecting sites of historical and cultural value. (6) Provide clear and targeted locations for recreation and natural tourism. (7) Recolonizing exploited areas. (8) Promote sustainable marine development.

Coastal borders have functions in their development, including:

a. Coastal harmony has a function as an area or zone that can support the oceans and infrastructure that is likely to develop naturally without the use of concrete or steel which can adversely affect the coast and its systems;

b. Damage to coastal land can also be reduced by coastal boundaries due to high waves. 
c. The general public can freely travel or have recreation on the beach because of the coastal border. Based on the above, it is clear that the coastline has an important function in the form of protection of the beach itself, but also has a recreational function for tourists. Coastal Borders have a strong enough correlation with RTH (Green Open Space) where the Perda RTRW Bali Province explains that Coastal Borders are part of the Green Open Space area. Talking about the implementation of regulations on the coastal border area, of course, we will discuss the legal protection of the coastal border area.

\subsection{The Influence of the Involvement of Traditional Village Elites on Strengthening the Identity of Local Institutions}

Bali is synonymous with tourism. Bali is an 'icon' of Indonesian tourism, Sutama (2013). Basically, the Balinese Traditional Spatial Pattern gives a lot of freedom to create and innovate without losing the spirit / spirit of traditional Balinese spatial planning itself. The steps to create Amed Beach towards sustainable marine tourism in this study are to assess or evaluate the development of Amed Beach and include it in the approach (4A). According to Medlik (1980) there are four aspects that must be considered in the tourism supply, these aspects are as :

a. Attractiveness; tourist destinations (hereinafter referred to as DTW) to attract tourists must have an attraction, both natural and community and cultural attractions.

b. Accessibility; intended so that domestic and foreign tourists can easily reach their destination to tourist attractions

c. Amenities; amenities are indeed one of the requirements for tourist destinations so that tourists can feel comfortable and stay longer at DTW.

d. Ancillary; The existence of a tourist tourism agency will increasingly visit and look for DTW if in that area tourists can feel security, (protection of tourism) and are protected.

In determining the steps to create a tourist attraction, it is necessary to pay attention to the 4A approach as described above. Where these four aspects are the most important basis for the sustainability of tourism and each of these components has a complementary relationship (Gautama \& Oa, 2011).

Development of Spatial Use in Coastal Areas as public spaces by establishing protected areas. The designation of this protected area has a main function, among others, to protect the preservation of the environment which includes natural resources, artificial resources and historical and socio-cultural values in the coastal area for the benefit of sustainable development in the coastal area of Amed Village.

The Tri Angga concept in Amed Traditional Village is motivated by the existence of the Catus Patha concept which is oriented to spatial structure and functions at a macro level, which can be used as a reference for micro spatial planning, namely on the border of Amed Beach even though the existence of a spatial structure (Catus Patha) in the Traditional Village Amed is not in accordance with the existing spatial structure in general in the Balinese traditional spatial concept, however the spirit / spirit of the Catus Patha concept can be drawn as a structuring reference in the scope of the study plan. Within the scope of the study (macro) the value concepts above are drawn into the scope of the study plan (micro) as a spatial arrangement such as at the Amed Beach border, so its manifestation lies in its zoning placement. The placement includes, among others. 1. The main zone in terms of prevailing values, the eastern / luan area is the main orientation area of community life. This means that this zone is intended for activities that are more sacred in nature, such as melasti, mesapel, removing melukat ash and so on in the Amed Beach area. 2. The middle / middle area / zone is the concentration of population activities with all its facilities and infrastructure such as places for residents to live, community activities / community interaction. 3. The downstream / teben zone is a concentration area for activities that support community economic factors such as recreation areas, surfing, and so on. The use of this concept is stated to exist if there is a division of space as above or close to it, this concept is related to other concepts. The implementation of the Tri Angga concept in the study location can be made into a spatial orientation based on the division of sacred and profane vertically and horizontally. Tourism has resulted in the changing functions of dwelling patterns from religious to economic function (Setiadi, 2007). 
In the results of research on customary institutions that support the development of the Sepadan Pantai Amed area, such as the government's efforts to provide educational supplies and inject funds to fishermen, want to make Amed Beach clean and beautiful, but all the efforts made have not touched all the ecological and social layers of Amed Beach. . Integrity between sectors is still not visible, all institutions move in their own ways and ways, never serious and sustainable, still doing it for the benefit of groups and individuals. Desa Adat as the holder of authority in the geneological territorial area of the local customary village is strict with the prevailing customary law system, conducts field studies, and conducts periodic evaluations of the performance of traditional village officials in the area of Amed traditional village.

The strategy for developing a coastal area in Amed village, such as providing a greenbelt/coastal green belt with various alternatives as follows: (1) at least 100 meters; (2) at least 200 meters; (3) at least 130 times the difference between the highest and lowest tides based on ecological criteria. a. Maintaining natural vegetation on the coastline. b. Perform rehabilitation on coastal boundaries where vegetation has been damaged / deforested. c. Maintain the coastal border by protecting the coastal area from activities that disturb the function of the coast and coastal ecosystems. d. Controlling and regulating the use of groundwater resources in seminal and coastal areas.

The development approach and coastal area development should be seen as an effort to utilize it in the context of environmental preservation. The scope of regulation of coastal areas and small islands includes transitional areas between land and sea ecosystems that are affected by changes in land and sea, towards land includes administrative areas of safety and sea direction as far as 12 (twelve) millauts measured from the coastline to the high seas (UU No 27 Tahun 2007).

It is a fact that any development program, its sustainability is very much determined by the supporting community. This means that the active participation of the community is absolutely necessary, so this model is a capital for community-based tourism. On a micro scale this paper will try to examine how the reality of tourism activities in Amed Traditional Village in terms of the uniqueness of the Amed Traditional Village both in terms of the physical environment, traditions and socio-cultural relations in the context of community-based tourism as sustainable tourism development. On this occasion, I also tried to provide suggestions as a solution to the challenges faced in the form of theoretical planning concepts so that the sustainability of tourism in Amed Traditional Village is sustainable and continues to apply the principles of sustainable cultural tourism based on community.

The Spatial Plan for the traditional village of Amed also regulates the Beach Border Green Open Space considering that environmental issues are the main topic in various circles of society, both international and Indonesian, one of which is global warming and the destruction of earth elements such as land, water and air. in the coastal area. Where the population and the needs and desires of the community make an increase in the development of industrial and physical development have a major effect on environmental damage. The impact of these conditions affects the transformation of ecosystem habitats, climate change, pollution, invasive species, and the reduction or loss of biodiversity (Syahfitri, 2020).

A tourist destination should be managed with planned management (Yoety, 2002), there are three reasons for community based management it is very important to be implemented as a basic design in development. First, there are local resources which are traditionally controlled and managed by local communities. Local people are seen as capable of managing their environment because they have inherited this wisdom from generation to generation. Second, there is local accountability, which means that management is carried out. by local people are usually more responsible, because the activities they carry out will directly affect their lives. Outsiders are seen as having no moral closeness to the local community, so they don't feel they have a high responsibility. Third, there are variations between regions (local variety), so that the coastal areas in the traditional village of Amed cannot be treated the same and demand a different management system. 


\subsection{Discussion}

The results showed:

a. The philosophy of Tri Hita Karana as a forum that accommodates harmonious attainment, $t$ was one of the philosophy that underlies all aspects of Balinese life in their interaction including on organizational life, Dewi et al (2018) (Purnamawati\& Adnyani, 2018), (Purnamawati \& Adnyani, 2019).

b. Tri Angga representing the luan/upstream teben/downstream which divides the zone into the main room/main Mandala, which is intended for sacred activities, located in a place that is higher than the surrounding area, is located in the direction of the kaja/utarakangin/east, (intermediate/Madya Mandala room, designated for worldly activities (residential areas and its infrastructure) and the Nista Mandala room, designated for utility activities, waste disposal, and facilities. supporting community activities both economically and socially, such as: places for recreation, trade and services, etc.

c. Meanwhile, the Sanga Mandala concept is a derivative of the Tri Angga concept which divides the zones into nine zones.

The spatial manifestation that occurs is based on a belief system, through a sense that is formed from a tradition that shapes a value system and spatial structure towards a harmonious framework with the involvement of the customary village elite.

Following up on a number of developments in community settlements in the Amed Traditional Village, it is necessary to pursue a strategic plan for the handling and preservation of cultural and social values of the community so that the development of the developing region does not have a significant negative impact on the existing developments in the Amed Traditional Village. For that, the recommendations to be submitted are: 1. Existence of traditional Balinese philosophical values and spatial concepts to maintain Balinese architectural values, it is necessary to emphasize that every building in Amed Traditional Village, both villas / bungalows, must at least contain Burde, Join Celedu and Balinese building ornaments as well as basic materials / colors of Balinese culture. Either brick red or sandstone color. Preserving the existence of spatial values in form, material, and function will be a strategic conservation effort in the management of residential buildings in the Amed Traditional Village.

The application of the concept of a spatial pattern which is a legacy from our ancestors whose purity must be maintained (Ajeg Bali). Therefore, the philosophy and concept of traditional Balinese spatial patterns needs to be considered in its existence into a regional regulation or regulation, especially in Bali. 2. Relocation of activity and utilization patterns Land Relocation / transfer of activities for both ritual activities, community activities and community support activities in spatial planning, an adjustment is needed between the existing conditions and the method used in relocating. Therefore, the relocation / transfer of an activity pattern and a spatial pattern must interpret the essence that regulates both spatial structure and behavior. 3 . The existence of aesthetic values the freedom to innovate and be creative in the philosophy and concept of traditional Balinese spatial patterns, which is not limited in flexibility, provides a deep meaning of harmonious achievement based on respect and respect. Beliefs, traditions, culture that contain aesthetic values that shape value systems and spatial planning, therefore environmental spatial planning must pay attention to traditional cultural values with an aesthetic value approach based on trust through sense as a preservation of cultural assets. The artistic value contained in an arrangement also has an impact on its own selling power in the tourism sector.

Local wisdom known as traditional knowledge, localknowledge and ethnoscience must be considered in the context of tourism development with cultural and environmental insight. The basic point of management activities in the concept of "community management" starts from the community itself, namely: identification of needs, analysis of capabilities and control over existing resources. 
The main supporting point for the position of traditional villages in tourism development is to take the initiative in improving the quality of human resources, such as:

a. Involving the community around the coastal border in the maintenance of vegetation and rehabilitation of the coastal border.

b. Conducting outreach on efforts to utilize and conserve coastal borders to all related development actors, especially communities around the area.

c. Application of incentives in efforts to conserve coastal border areas on privately controlled lands.

d. The application of disincentives through the imposition of high taxes on third parties which results in changes in land use in the coastal border area.

e. Actively involving the local community in controlling utilization in the form of; monitoring, supervision and control of coastal border areas.

\section{References}

Adnyani, N. K. S. (2016). Perlindungan Hukum Melalui Permodelan Simulasi Terpadu Ekologi Bahari Berdasarkan Peran Wanita Pesisir Nusa Penida. Jurnal Ekonomi Dan Pariwisata UNDHIRA Bali, 11(2), 20-31.

Bengen, G. D. (2000). Penentuan dan Pengelolaan Kawasan Lindung di Pesisir, Laut dan PulauPulau Kecil. Jakarta.

Dalem, A. A. G. R. (2014). Achievements and challenges of implementation of "Tri Hita Karana" for creating sustainable tourism in Bali-Indonesia: A case study in hotel sectors.

Dewi, I. G. A. A. O., Dewi, I. G. A. A. P., Kustina, K. T., \& Prena, G. Das. (2018). Cultureof Tri Hita Karana on Ease of Use Perception and Use of Accounting Information System. International Journal of Social Sciences and Humanities, 2(2), 77-86. https://doi.org/10.29332/ijssh.v2n2.131

Djunarjah, E. (2011). Urgensi Penetapan Batas Laut Berkaitan Dengan Pelaksanaan Otonomi Daerah. Bandung: FTSP-IPB.

Gautama, I. A. G. O. (2011). Evaluasi Perkembangan Wisata Bahari di Pantai Sanur. Universitas Udayana.

Gede, P. I. (2010). Tri Hita Karana-The Local Wisdom of the Balinese in Managing Development. Trends and Issues in Global Tourism, 139-150. https://doi.org/10.1007/978-3-642-108297 - 18

Hakim, B. R., \& Setiadi, A. (2016). Bali Traditional Settlement Morphology Analysis Penglipuran, Kubu Village, Bangli Regency, Bali Province. DIMENSI Journal of Architecture and Built Environment, 43(1), 47-54.

Pemayun, I. D. G. A., \& Meirejeki, I. N. (2017). Harmonization of Tri Hita Karana and Cultural Tourism Bali. Soshum: Jurnal Sosial Dan Humaniora, 6(2), 200-206.

Purnamawati, I. G. A. (2021). Sustainable Tourism Development Through Improving the Role of Customary Village. International Journal of Social Science and Business, 5(1), 26-33. https://doi.org/10.23887/ijssb.v5i1.30778

Purnamawati, I. G. A., \& Adnyani, N. K. S. (2019). Peran Komitmen, Kompetensi, dan Spiritualitas dalam Pengelolaan Dana Desa. Jurnal Akuntansi Multiparadigma, 10(2), 227-240. https://doi.org/10.18202/jamal.2019.08.10013

Purnamawati, I. G. A., \& Adnyani, N. K. S. (2021). Traditional Villages And Tourism Integration Model For Inclusive Social Economy. Yurisprudentia: Jurnal Hukum Ekonomi, 7(1), 77-92. https://doi.org/10.24952/yurisprudentia.v7i1.3801

Purnamawati, I. G. A., Adnyani, N. K. S., \& Suastika, I. N. (2015). The Conservation of Perang Pandan Tradition for the Socio-Economic Life of Adat Community in Tenganan Pagringsingan Bali. In Procedia-Social and Behavioral Sciences (pp. 135-141). Denpasar, Bali: Science Direct, Elsevier. https://doi.org/10.1016/j.sbspro.2015.11.020 
Sudiatmaka, K., Adnyani, N. K. S., \& Windari, R. A. (2016). Putusan MUDP Bali No. 01/Kep/PSM3MDP Bali/X/2010 Sebagai Legitimasi Formal Anak Perempuan Berhak Mewaris di Kabupaten Buleleng. In Seminar Nasional Riset Inovatif. Sanur, Bali: Undiksha Press.

Sutama, I. K. (2013). Pariwisata Spiritual di Bali dari Perspektif Stakeholders Pariwisata. Jurnal Perhotelan Dan Pariwisata, 3(2), 1.

Syahfitri, C. N. (2020). Implementasi Kebijakan Pengembangan Ruang Terbuka Hijau Sempadan Pantai Di Kota Cirebon Provinsi Jawa Barat. Jurnal Kebijakan Pemerintahan, 3(2), 62-74. https://doi.org/10.33701/jkp.v3i2.1306

Yoeti, O. A. (2002). Perencanaan Strategis Pemasaran Daerah Tujuan Wisata. Jakarta: Pradnya Paramita. Retrieved from https://openlibrary.telkomuniversity.ac.id/pustaka/101131/perencanaan-strategis-pemasarandaerah-tujuan-wisata.html

Yudana, I. M., Landrawan, I. W., \& Adnyani, N. K. S. (2020). Pemberdayaan Sekaa Truna-Truni (STT) Stithi Aji Dharma Pemuteran Dalam Pengelolaan Kawasan Wisata. In Proceeding Seminar Nasional Pengabdian Masyarakat (p. 107). 